\title{
REVIEW ATAS PELAKSANAAN KETENTUAN PAJAK PENERANGAN JALAN DI INDONESIA ${ }^{1}$
}

\author{
Maria R.U.D. Tambunan* dan Haula Rosdiana \\ Departemen Ilmu Administrasi Fiskal Universitas Indonesia \\ Prajudi Atmosudirdjo Building, Fakultas Ilmu Administrasi UI, Depok, 16424 \\ maria.tambunan@ui.ac.id
}

\begin{abstract}
The stipulation of Law No. 28/2009 concerning Local Tax and User Charges has granted huge fiscal authority for local government to optimize its revenue potential. One of the potential sectors available to optimize as regulated on Law No. 28/2009 is levying tax on road electricity. This article is intedended to review the implementation of tax on road electricity on the aspect of the tax policy, and the administration of collected tax revenue by reflecting the theoretical perspective of how it should levy taxes. This study used qualitative method, data collection was performed through literature review and documentation study. The research shows that the substantial note need to consider as the result of the current implementation is that the flaw of tax subject and tax object whereas that determination would have affected the tax treatment for the taxpayer followed by the tax burden dan tax administration fulfillment.
\end{abstract}

Keywords: Tax on Road Electricity; Local Tax; Fiscal Decentralization

\begin{abstract}
Abstrak
Diundangkannya Undang-Undang No. 28 Tahun 2009 tentang Pajak Daerah dan Retribusi Daerah memberikan kewenangan yang cukup besar bagi Pemerintah Daerah untuk menggali potensi penerimaan daerahnya. Salah satu jenis penggalian potensi yang diuraikan dalam Undang-undang tersebut adalah pemungutan Pajak atas Penerangan Jalan. Artikel ini bertujuan untuk mereview kebijakan pengenaan Pajak Penerangan yang diulas dari aspek kebijakan pajak, tata kelola dan administrasi pajak sebagaimana seharusnya dengan berpedoman pada konsep dan teori perpajakan. Penelitian ini menggunakan metode kualitatif dengan pengumpulan data dengan studi pustaka. Penelitian ini menunjukkan catatan penting bahwa dalam Undang-undang tersebut, tidak cukup jelas apakah jenis pungutan pajak tersebut merupakan pajak suatu subyektif atau pajak obyektif, sementara hal tersebut akan berpengaruh pada perlakuan bagi wajib pajaknya, berikut beban pajak yang harus ditanggung serta konsekuensi administrasi perpajakan yang harus dilaksanakan.
\end{abstract}

Kata Kunci: Pajak Penerangan Jalan; Pajak Daerah; Desentralisasi Fiskal

\footnotetext{
${ }^{1}$ Artikel hasil penelitian mandiri yang dilakukan penulis pada tahun 2018.
} 


\section{A. Pendahuluan}

Sejak diberlakukannya UU No. 22 Tahun 1999 tentang Pemerintah Daerah dan UU No. 25 Tahun 1999 tentang Perimbangan Keuangan Pusat dan Daerah, telah terjadi pelimpahan kewenangan yang semakin luas kepada pemerintah daerah dalam rangka meningkatkan efektivitas dan efisiensi penyelenggaraan fungsi pemerintah daerah (Ismail, 2011). Penyelenggaraan fungsi pemerintah daerah yang lebih luas oleh pemerintah daerah tersebut perlu didukung oleh sumber pembiayaan yang memadai. Pada kenyataannya, sumbersumber penerimaan antar satu daerah dengan daerah lainnya sangat beragam dan memiliki karakteristik masing-masing yang baik secara langsung maupun tidak langsung dipengaruhi oleh keadaan alam, kultur dan karakteristik masyarakat (Prathama G.A., 2018). Hal ini pulalah yang menyebabkan terdapat beberapa daerah dengan sumber daya yang dimiliki mampu menyelanggarakan otonomi daerah namun tidak tertutup kemungkinan adanya beberapa daerah yang akan menghadapi kesulitan dalam menyelenggarakan tugas desentralisasi sehubungan dengan keterbatasan sumber daya yang dimiliki (Iskandar, 2014).

Kreativitas dan inisiatif suatu daerah dalam menggali sumber keuangan akan sangat tergantung pada kebijakan yang diambil oleh pemerintah daerah tersebut. Mobilisasi sumber daya keuangan dalam membiayai berbagai aktivitas pemerintahan daerah diharapkan mampu meningkatkan kinerja pemerintah daerah. Hal ini diharapkan dapat mendorong dalam menjalankan fungsinya sehingga perlu dilakukan pengkajian mendalam mengenai kapasitas dan kemampuan keuangan daerah serta bagaimana strategi untuk memaksimalkan pendapatan asli daerah (PAD) (Wardhono A., Indrawati Y., 2012).

Sumber pendapatan daerah terdiri dari penerimaan asli daerah (PAD), dana perimbangan, pinjaman daerah dan penerimaan daerah lainnya yang sah. Adapun belanja daerah dirinci berdasarkan organisasi, fungsi dan jenis belanja (Hakim M; Sarma Ma'mun; Hariyanto, 2018). Kajian kemampuan keuangan daerah pada studi ini dibatasi pada sisi penerimaan dan fokus pada aspek PAD. PAD merupakan fokus perhatian dan menjadi krusial karena pada dasarnya otonomi daerah ditujukan untuk meningkatkan kemandirian daerah. Pengukuran kemandirian daerah ini seringkali diterjemahkan sebagai capaian PAD. Selain itu, tidak kalah krusialnya yaitu untuk membiayai kewenangan daerah, PAD idealnya menjadi sumber pendapatan pokok daerah. Sumber pendapatan daerah lainnya bisa bersifat fluktuatif dan cenderung diluar kontrol kewenangan daerah. Dengan kewengan yang semakin besar yang dimiliki oleh pemerintah daerah, diharapkan mampu meningkatkan PAD (Hari, 2012).

Secara teoritis, untuk merespon tekanan fiskal, pemerintah dapat memilih dari beberapa pilihan strategi (Fan, 2016). Pertama, pemerintah daerah dapat mencari penerimaan tambahan melalui beberapa cara seperti meningkatkan retribusi daerah, meningkatkan pajak daerah, memperkenalkan pajak baru dan menjual asset yang tidak produktif. Kedua, pemerintah daerah dapat meningkatkan efisiensi dan efektivitas melalui program peningkatan produktivitas; perencanaan dan penganggaran yang lebih efisien; menghilangkan beberapa program yang kurang signifikan; menggunakan pendekatan low cost atau meningkatkan penghematan melalui penggunaan sektor publik. Ketiga, pemerintah daerah dapat mengurangi lingkup aktivitas mereka dengan lebih menggunakan sektor swasta untuk menyediakan pelayanan publik dibawah self-activity system dan mobilisasi sumber daya non pemerintah. Namun, jika kembali pada semangat kemandirian dan maksimalisasi potensi penerimaan, maka pilihan pertama merupakan pilihan utama, yaitu optimalisasi penerimaan pajak daerah dan retribusi daerah.

Ketentuan perpajakan Indonesia melalui UU No.28/2009 tentang Pajak Daerah dan Retribusi Daerah memberikan kewenangan 
kepada Pemerintah Daerah untuk melakukan beberapa hal strategis dan mendasar terkait desentralisasi fiskal. Hal ini pulalah yang mengakibatkan perubahan yang besar terkait hubungan keuangan pusat dan daerah. Dalam hal kapasitas fiskal daerah, adanya Undang-undang ini memberikan kewenangan kepada Pemerintah Daerah untuk mengatur pemajakan dan pemungutan retribusi untuk membiayai penyelenggaraan kegiatan pemerintahannya sebagai salah satu sumber Pendapatan Asli Daerah (Rahman F.A., 2017). Diundangkannya UU No.28/2009 tentang Pajak Daerah dan Retribusi Daerah memberikan kewenangan kepada Pemerintah Daerah untuk melakukan pemungutan Pajak atas Penerangan Jalan (PPJ) melalui suatu rumusan kebijakan yang kemudian dituangkan dalam ketentuan formal. Pajak penerangan jalan yang dimaksud dalam UU dalam Pasal 1(28) tersebut adalah pajak atas penggunaan tenaga listrik, baik yang dihasilkan sendiri maupun diperoleh dari sumber lain.

Dalam merumuskan kebijakan perpajakan, perlu mempertimbangkan halhal berikut: (1) dalam pemungutan pajak, pelaksanaannya tidak selayaknya memfokuskan pada pemaksaan karena prinsipnya pajak merupakan wujud kesadaran masyarakat dalam memberikan kontribusi kepada negara; (2) model pemungutan pajak tidak mengutamakan pemaksaan agar pendefinisian pajak menjadi lebih netral dan tidak berkonotasi negatif, terutama untuk membedakan antara negara merdeka dan negara yang masih terjajah yang harus membayar pajak kepada negara yang menjajahnya; (3) pajak harus dikembalikan ke masyarakat, sehingga seharusnya hasil penerimaan pajak tidak digunakan semata-mata untuk membayar hutang atau menutup defisit anggaran (Hadi, 2017); (4) pajak memiliki pengukuran manfaat yang diterima masyakat, setidaknya adanya transparansi pemerintah menunjukkan bahwa hasil pajak digunakan untuk membangun infrastruktur, subsidi pendidikan, pelayanan dan investasi publik lainnya (Richard, 2012).
Adapun kewenangan pemajakan tesebut diuraikan melalui Pasal 52 (1) UU Pajak Daerah dan Retribusi Daerah yang menyebutkan bahwa "Objek Pajak Penerangan Jalan adalah penggunaan tenaga listrik, baik yang dihasilkan sendiri maupun yang diperoleh dari sumber lain". Selanjutnya, Pasal 53 (1) menyebutkan bahwa Subjek Pajak Penerangan Jalan adalah Orang Pribadi atau Badan yang dapat menggunakan tenaga listrik, (2) Wajib Pajak Penerangan Jalan adalah orang pribadi atau Badan yang menggunakan tenaga listrik dan pada Pasal (3) Dalam hal tenaga listrik disediakan oleh sumber lain, Wajib Pajak Penerangan Jalan adalah penyedia tenaga listrik. Selain itu, terkait pemanfaatan dan redistribusi dari penghimpunan PPJ, UU No. 28/2009 Pasal 56 (3) mengatur bahwa "Hasil penerimaan Pajak Penerangan Jalan sebagian dialokasikan untuk penyediaan penerangan jalan". Jika mengacu pada konsep penyusunan pajak daerah, termasuk Pajak Penerangan Jalan, perlu memperhatikan setidaknya aspek-aspek berikut (Scheerens D; Ongevalle J.V., 2018): (1) Kecukupan dan elastisitas, yaitu memadai tidaknya hasil suatu pajak dalam kaitan dengan berbagai layanan yang dibiayai, stabilitas \& mudah tidaknya memperkirakan besar hasil tersebut dan elastisitas hasil pajak terhadap inflasi, pertumbuhan penduduk, serta perbandingan hasil pajak dengan biaya pemungutannya; (2) Keadilan, dimana dasar pengenaan pajak dan kewajiban membayar harus jelas dan tidak sewenangwenangan serta memperhatikan prinsip keadilan horizontal maupun vertikal, adil terhadap suatu subyek pajak terhadap subyek pajak lainnya; (3) Kelayakan administrasi, dimana berbagai jenis pajak berbeda mengenai jumlah, integritas dan keputusan yang diperlukan dalam menjalankan kegiatan administrasinya. Selain itu, dalam penerapannya diperlukan sistem administrasi yang mudah dan sederhana; (4) Kesepakatan politis, dimana pajak dalam keputusan penetapan struktur, besarnya tarif, siapa yang harus membayar, 
sanksi terhadap pelanggar merupakan kesepakatan politis antara eksekutif dengan legislatif sebagai representasi masyarakat; dan (5) Distorsi ekonomi, dimana pajak hendaknya mendorong penggunaan sumber daya untuk memaksimalkan utilitas dengan demikian pajak tidak seharusnya menjadi tambahan beban bagi masyarakat yang mempengaruhi tingkat konsumsi.

Dengan ketentuan yang diatur dalam peraturan terkait Pajak Penerangan Jalan (PPJ) saat ini, akan berpotensi menimbulkan kesulitan dalam implementasinya karena adanya ketidakselarasan antara ketentuan yang ditetapkan dan bagaimana konsep pemungutan pajak yang seharusnya. Artikel ini akan membahas lebih lanjut terkait kebijakan pengenaan Pajak Penerangan dari aspek kebijakan pajak, tata kelola/governansi dan administrasi pajak dan hal-hal yang perlu diperhatikan terkait teknis pelaksanaan kebijakan pemungutan Pajak Penerangan Jalan (PPJ). Artikel ini diharapkan dapat menjadi suatu bahan pertimbangan ketika akan mendesain suatu kebijakan pemajakan.

\section{B. Metode Penelitian}

Penelitian ini menggunakan pendekatan kualitatif. Penelitian kualitattif merupakan penelitian yang ditujukan untuk mengungkapkan permasalahan sosial yang ingin diselesaikan dengan melakukan pemahaman mendalam terhadap permasalahan tersebut. Berdasarkan tujuannya penelitian ini merupakan penelitian kualitatif deskriptif yang bertujuan untuk memberikan gambaran spesifik tentang implementasi kebijakan atas pajak pemungutan jalan. Dalam penelitian ini teknik pengumpulan data yang digunakan adalah teknik pengumpulan data kualitatif melalui studi kepustakaan. Studi kepustakaan dilakukan dengan mencari data sekunder yang diperoleh dari berbagai sumber antara lain buku, artikel, dan publikasi elektronik.

\section{Hasil dan Pembahasan}

\section{Analisis atas Pemungutan dan Redistribusi Pajak Penerangan Jalan}

Sebuah kebijakan pajak dikatakan baik apabila hal-hal berikut terkait dengan tax base telah ditentukan dengan jelas terkait: (a) siapa yang akan dikenakan pajak, (b) siapa yang dikecualikan dari pengenaan pajak, (c) apa yang dijadikan sebagai subyek pajak, (d) bagaimana menentukan prosedur pelaksanaan kewajiban pajak terutang (Richard, 2012). Jika memperhatikan kebijakan pajak penerangan jalan di Indonesia, dalam hal penentuan subyek pajaknya, maka coverage dari subyek pajak tersebut cukup luas, yaitu meliputi orang pribadi atau badan yang dapat menggunakan tenaga listrik. Sementara, yang menjadi Wajib Pajak dalam ketentuan tersebut adalah orang pribadi atau badan yang menggunakan tenaga listrik. Dalam hal tenaga listrik disediakan oleh sumber lain, maka yang menjadi wajib pajak penerangan jalan adalah penyedia tenaga listrik.

Selanjutnya, dalam Pasal 52(2) disebutkan bahwa listrik yang dihasilkan sebagai obyek Pajak Penerangan Jalan (PPJ) meliputi seluruh pembangkit listrik. Hal-hal yang dikecualikan sebagai obyek Pajak Pengerangan Jalan sebagaimana diatur dalam Pasal 52(3) meliputi: (a) Penggunaan tenaga listrik oleh instansi Pemerintah Pusat dan Pemerintah Daerah; (b) penggunaan tenaga listrik pada tempat-tempat yang digunakan oleh kedutaan, konsulat, dan perwakilan asing dengan asas timbal balik; (c) penggunaan tenaga listrik yang dihasilkan sendiri dengan kapasitas tertentu yang tidak memerlukan izin dari instansi teknis terkait; dan (d) penggunaan tenaga listrik lainnya yang diatur dengan Peraturan Daerah

Dalam pengklasifikasian apakah PPJ merupakan jenis pajak subyektif atau pajak obyektif, maka berdasarkan penentuan subyek pajak maupun wajib pajaknya, maka hal tersebut tidak cukup jelas. Santoso Brotodiharjo (1993) menyebutkan bahwa pajak subyektif adalah pajak yang 
memperhatikan keadaan wajib pajaknya, yaitu untuk menetapkan pajak yang akan dipungut harus ditemukan alasan-alasan yang berhubungan erat dengan keadaan materialnya, yaitu yang disebut dengan ability-to-pay, dimana besarnya ability-topay dapat diukur berdasarkan faktor penghasilan, konsumsi atau kekayaan. Dalam tataran praktis, Brotodiharjo menyebutkan bahwa pajak subyektif dimulai dari menetapkan seseorang sebagai subyek pajak, kemudian dicarikan syarat-syarat obyektifnya. Sementara, pajak obyektif dimulai dengan obyeknya terlebih dahulu seperti keadaan, peristiwa, perbuatan dan lain-lain, kemudian dicarikan orang yang akan menjadi subyek pajaknya. Dalam pelaksanaan Pajak Penerangan Jalan, penetapan subyek pajak maupun wajib pajak dapat terdiri dari pengguna maupun penghasil tenaga listrik, dimana penekanan penting dari jenis pajak ini adalah bahwa tenaga listrik telah digunakan atau konsumsi terhadap adanya penyediaan listrik. Artinya, jenis pajak ini menekankan bahwa terdapat obyek pajak yang atasnya dapat dicarikan subyek.

Meskipun demikian, tidak pula konsisten dengan pemajakan berdasarkan konsumsi karena juga menyebutkan bahwa dalam Pasal 54 (2b) dalam hal tenaga listrik dihasilkan sendiri, nilai jual tenaga listrik dihitung berdasarkan kapasitas tersedia, tingkat penggunaan listrik, jangka waktu pemakaian listrik, dan harga satuan listrik yang berlaku di wilayah daerah yang bersangkutan. Hal ini menunjukkan bahwa bagi Wajib Pajak tertentu, terdapat potensi untuk dikenakan pajak tidak sesuai atau bahkan kurang dari jumlah konsumsi, sebab terdapat kelaziman bahwa pembangkitan listrik pada umumnya menggunakan listrik yang dihasilkan di bawah kapasitas produksi dengan untuk tujuan keandalan mesin pembangkit listrik untuk jangka panjang. Kapasitas produksi tidak serta merta sama dengan jumlah konsumsi atau bahkan kapasitas produksi pada umumnya lebih tinggi dari jumlah konsumsi atau jumlah konsumsi ril lebih rendah dari kapasitas produksi (wawancara mendalam dengan ahli). Ketentuan yang demikian telah melanggar prinsip keadilan bagi wajib pajak karena wajib pajak dibebankan suatu pungutan yang kemungkinan tidak sesuai dengan besarnya konsumsi yang dilakukan, jika pajak tersebut dikenakan atas konsumsi.

Namun, apabila jenis pajak ini tetap akan diklasifikasikan ke dalam pajak obyektif, yaitu tidak memperhatikan keadaan subyek pajak/wajib pajaknya, pada kenyataannya dalam UU yang mengatur, terdapat pembeda terkait perhitungan yang disebabkan oleh perbedaan tarif. Perbedaan tarif tersebut seyogiya menunjukkan bahwa atas siapa dibebankan pajak tersebut menjadi tidak obyektif, atau masih memperhatikan keadaan subyek pajaknya. Pasal 55 mengatur sebagai berikut: (a) Tarif Pajak Penerangan Jalan ditetapkan paling tinggi sebesar 10\% (sepuluh persen); (b) Penggunaan tenaga listrik dari sumber lain oleh industri, pertambangan minyak bumi dan gas alam, tarif Pajak Penerangan Jalan ditetapkan paling tinggi sebesar 3\% (tiga persen); dan (c) Penggunaan tenaga listrik yang dihasilkan sendiri, tarif Pajak Penerangan Jalan ditetapkan paling tinggi sebesar $1,5 \%$ (satu koma lima persen). Dengan demikian, adanya ketidakkonsistenan dalam pengklasifikasian akan berdampak pada pilihan kebijakan yang tepat dan nantinya akan berdampak pada teknis dan administrasi pemungutan pajaknya.

Adapun pengecualian pengenaan Pajak Penerangan Jalan pada Pasal 52 disebutkan bahwa pengenaan pajak dikecualikan dari obyek pajak ini terdiri dari: (a) penggunaan tenaga listrik oleh instansi Pemerintah dan Pemerintah Daerah, (b) penggunaan tenaga listrik pada tempat-tempat yang digunakan oleh kedutaan, konsulat, dan perwakilan asing dengan asas timbal balik; (c) penggunaan tenaga listrik yang dihasilkan sendiri dengan kapasitas tertentu yang tidak memerlukan izin dari instansi teknis terkait dan (d) penggunaan tenaga listrik lainnya yang diatur dengan Peraturan Daerah. Dengan pembatasan pengecualian yang 
demikian terbatas, dapat dilihat bahwa pada dasarnya pemungutan Pajak Penerangan Jalan bersifat umum (general) seperti pajak atas konsumsi yang pada dasarnya dikenakan pada semua barang dan jasa, dengan pengecualian tertentu yang jumlahnya tidak cukup besar.

Namun, perlu diingat bahwa pada dasarnya penyediaan listrik merupakan jenis barang (public goods) yang seyogiyanya disediakan oleh pemerintah, berbeda dengan barang konsumsi lainnya yang bersifat privat. Dalam teori klasik keuangan negara, penyediaan barang-barang dengan karakteristik berikut merupakan jenis barang publik, dimana penyediaan listrik termasuk didalamnya, merupakan salah satu fungsi dari negara (Szalbierz Z., 2016). Adapun hal-hal yang perlu diperhatikan terkait penyediaan barang public sebagai berikut (Kallhoff, 2014): (a) Barang publik memiliki karakteristik non-rivalry dan nonexcludable, hal ini merupakan pembeda mendasar antara barang publik dan barang privat; (b) Non-rivalry artinya, konsumsi suatu individu tidak dapat membatasi/mencegah konsumsi orang lain. Seseorang tidak dapat membatasi akses orang lain untuk mengkonsumsi barang/jasa yang sama semata-mata karena seseorang tersebut mampu membeli barang tersebut; dan (c) Non-excludable artinya, konsumsi seorang individu atas suatu barang/jasa tidak mengakibatkan penurunan/pengurangan atas konsumsi orang lain. Meskipun seseorang menggunakan barang tersebut, masih terdapat sejumlah banyak tersisa barang/jasa yang sama bagi orang lain.

Secara sederhana dapat digambarkan seperti pada Tabel 1. Dari Tabel 1 dapat dilihat bahwa penyediaan listrik dapat dikatorikan ke dalam collective goods, namun penerangan merupakan pure private goods yang seyogiyanya disediakan sepenuhnya oleh pemerintah. Dengan kata lain, pemungutan Pajak Penerangan Jalan (PPJ) semata-mata untuk digunakan sebagai pembiayaan pengadaan penerangan jalan, maka praktik tersebut pada dasarnya belum memenuhi konsep barang dan jasa publik.
Bahkan Das-Gupta (2015) menambahkan beberapa karakteristik lainnya terkait barang/jasa publik seperti: (a) memiliki cakupan geografis yang luas, (b) kemungkinan terjadi asymetric information atas penyediaan barang tersebut diantara para penggunanya, pengadaan/produksinya dalam jumlah yang sangat besar dalam suatu termin produksi, (d) dapat menimbulkan eksternalitas atas penggunaannya (Das-Gupta A., 2015).

Tabel 1.

Klasifikasi Barang Publik

\begin{tabular}{lll}
\hline Excludable & \multicolumn{2}{c}{ Rival } \\
\hline Ya & Ya & Tidak \\
& $\begin{array}{l}\text { Pure public } \\
\text { goods } \\
\text { (pertahanan, } \\
\text { penerangan) }\end{array}$ & $\begin{array}{l}\text { Common } \\
\text { goods } \\
\text { (perikanan } \\
\text { lepas pantai, } \\
\text { penambangan } \\
\text { SDA) }\end{array}$ \\
Tidak & $\begin{array}{l}\text { Collective } \\
\text { goods } \\
\text { (TV Kabel) }\end{array}$ & $\begin{array}{l}\text { Private Goods } \\
\text { (makanan, } \\
\text { kendaraan) }\end{array}$ \\
\hline
\end{tabular}

Sumber: Angela Kallhoff (2014) Why Society Needs Public Goods

Kemungkinan pengenaan Pajak Penerangan Jalan atas penggunaan tenaga listrik ditujukan untuk memenuhi prinsip earmarking, akibat dampak eksternalitas penggunaannya. Earmarking sendiri secara konseptual merupakan pajak yang dipungut untuk membiayai berbagai pengeluaran spesifik sebagai dampak dari kegiatan yang atasnya dipungut pajak. Earmarking dapat didefinisikan sebagai "...a contribution means that its revenue will have to be spent on a specific predefined prupose..." (Hundsdoefer J. [et.al], 2013). Mengingat pemungutan pajak mempunyai fungsi yang sangat strategis, sehingga digunakan sebagai instrumen kebijakan pemerintah untuk mencapai tujuan tertentu. Dalam Pasal 56 (3) mengatur bahwa "Hasil penerimaan Pajak Penerangan Jalan sebagian dialokasikan untuk penyediaan penerangan jalan". Membedah konsep earmarking, 
bahwa salah satu bentuk pajak yang dipungut untuk tujuan tertentu adalah earmarked, yaitu tax collected and used for specific purpose. Pada umumnya, pemungutan pajak dengan tujuan earmarked melekat dengan pengembalian manfaat kepada masyarakat secara langsung melalui berbagai penyediaan jenis layanan publik (Rosdiana, 2007). Adapun jenis-jenis earmarking yang umum diterapkan adalah sebagai berikut:

\section{Tabel 2.}

Variasi Pendekatan Earmarking

\begin{tabular}{|c|c|c|c|}
\hline $\begin{array}{l}\text { Tipe } \\
\text { A }\end{array}$ & $\begin{array}{l}\text { Penerimaan } \\
\text { (revenue) }\end{array}$ & $\begin{array}{l}\text { Pengeluaran } \\
\text { (expenditure) }\end{array}$ & Contoh \\
\hline A & $\begin{array}{l}\text { Pajak atau } \\
\text { non pajak } \\
\text { tertentu }\end{array}$ & $\begin{array}{l}\text { Penggunaan } \\
\text { akhir tertentu }\end{array}$ & $\begin{array}{l}\text { Pajak BBM } \\
\text { dan PNBP } \\
\text { atas } \\
\text { kendaraan } \\
\text { bermotor } \\
\text { untuk } \\
\text { investasi } \\
\text { jalan raya } \\
\text { dan } \\
\text { keamanan } \\
\text { social. Dana } \\
\text { sosial untuk } \\
\text { pemberdayaa } \\
\text { n masyarakat }\end{array}$ \\
\hline B & $\begin{array}{l}\text { Pajak atau } \\
\text { non pajak } \\
\text { tertentu }\end{array}$ & $\begin{array}{l}\text { Pengguna } \\
\text { akhir umum }\end{array}$ & $\begin{array}{l}\text { Pajak } \\
\text { tembakau, } \\
\text { alcohol } \\
\text { untuk sektor } \\
\text { sosial }\end{array}$ \\
\hline $\mathrm{C}$ & Pajak umum & $\begin{array}{l}\text { Pengguna } \\
\text { akhir tertentu }\end{array}$ & $\begin{array}{l}\text { Persentase } \\
\text { dari total } \\
\text { pendapatan } \\
\text { negara untuk } \\
\text { Pendidikan. } \\
\text { Bagian } \\
\text { penerimaan } \\
\text { (revenue } \\
\text { sharing) } \\
\text { untuk } \\
\text { kegiatan } \\
\text { tertentu }\end{array}$ \\
\hline D & Pajak umum & $\begin{array}{l}\text { Pengguna } \\
\text { akhir umum }\end{array}$ & $\begin{array}{l}\text { Bagian } \\
\text { penerimaan } \\
\text { (revenue } \\
\text { sharing) }\end{array}$ \\
\hline
\end{tabular}

Source: Suki Hariawan (2011), dikutip dari www.pnbp.net.
Das-Gupta, mengutip ide dari Bird (1997) dan Buchanan (1963) mengatakan bahwa sebenarnya justru konsep earmarked taxes tersebut tidak dikenal dalam teori ekonomi karena justifikasi pemungutannya tidak cukup kuat. Prinsip dasar dari optimasi fungsi pengeluaran pemerintah adalah bahwa marginal social benefit yang diperoleh masyarakat atas per unit mata uang yang disetorkan ke khas negara seharusnya setara. Artinya, jika pemerintah menggunakan justifikasi untuk memberikan manfaat kepada masyarakat dengan cara memungut pajak tertentu untuk tujuan tertentu, maka hal tersebut menunjukkan ketidakefisienan pemerintah dalam mengalokasikan sumber daya. Das-Gupta mengatakan, " the basic principle for an optimal goverment expenditure allocation is that the marginal social benefit per monetary unit of public expenditure should be equal across all activities. If the lower bound introduced on allocation to particular activities by earmarked taxes exceeds the optimal allocation, expenditure allocation will be inefficient"(Das-Gupta A., 2015).

Das-Gupta (2015) menambahkan bahwa saat ini pemajakan dengan justifikasi menjalankan earmarked semakin masif, bahkan terdapat sejumlah basis pemajakan baru yang sebenarnya secara ekonomi tidak dapat diberikan justifikasi namun dapat diterima secara politis (Das-Gupta A., 2015). Jika merefleksikan pernyataan tersebut dalam konteks pemungutan pajak atas penggunaan listrik untuk fungsi penerangan jalan, maka hal ini merupakan salah satu contoh praktik semakin masifnya basis pemajakan earmarked, dimana pada dasarnya penyediaan listrik maupun penerangan jalan merupakan salah satu tanggung jawab pemerintah dalam penyediaannya. Pemungutan kembali pajak atas penggunaan listrik yang sebagian akan dialokasikan untuk penerangan jalan pada dasarnya merupakan cerminan bahwa pemerintah belum mampu mengalokasikan anggaran secara efisien dan berkualitas.

Argumen yang kemungkinan digunakan untuk melakukan pemungutan atas 
penggunaan listrik adalah membatasi penggunaannya atau untuk mengurangi eksternalitas negative atas penggunaan yang berlebihan. Apabila tujuan adanya pungutan terhadap penggunaan listrik yang berlebihan atau pembatasan penggunaan listrik, maka konsep pengenaan cukai juga dapat dipertimbangkan. Cukai merupakan pungutan atas konsumsi barang atau jasa tertentu karena potensi dampak negatif yang ditimbulkan akibat konsumsinya dan dalam keadaan tertentu, permintaan atas barang ini tergolong inelastis sehingga perlu upaya untuk membatasinya. Dalam konsep cukai ini, terdapat penekanan penting yaitu bahwa konsumsi akan menimbulkan dampak eksternalitas bagi lingkungannya. Mengutip Giertz (2007) menyebutkan bahwa "excises are also levied on goods or services that are considered harmful or undesirable, in attempt to discourage consumption. Taxes based on this rationale are labelled sumptuary excises, for example includes taxes on alcholic beverages, tobacco products. Because many of goods and services taxed by sumptuary excises have relatively inelastic demands, these taxes may have only limited impact on curtailing consumption".(Giertz, 2007)

Berhubung bahwa cukai merupakan bagian pemajakan atas konsumsi, maka perlu memberikan pembeda secara konseptual terkait pajak atas konsumsi yang berlaku secara umum, seperti Pajak Pertambahan Nilai/Pajak atas Barang dan Jasa/Pajak Penjualan dengan konsep cukai agar keduanya menjadi jelas.

Tabel 3.

Perbedaan Cukai dengan Pajak atas Konsumsi Lainnya

\begin{tabular}{llrl}
\hline No & \multicolumn{1}{c}{ Cukai } & \multicolumn{1}{c}{$\begin{array}{c}\text { Pajak atas Konsumsi } \\
\text { (Sales Tax) }\end{array}$} \\
\hline 1 & $\begin{array}{l}\text { Selective in } \\
\text { coverage } \\
\text { Obyek cukai hanya } \\
\text { atas barang dan jasa } \\
\text { tertentu }\end{array}$ & $\begin{array}{l}\text { General taxes } \\
\text { Obyek pajak adalah } \\
\text { semua barang dan jasa }\end{array}$ \\
&
\end{tabular}

\begin{tabular}{|c|c|c|}
\hline No & Cukai & $\begin{array}{c}\text { Pajak atas Konsumsi } \\
\text { (Sales Tax) }\end{array}$ \\
\hline 2 & $\begin{array}{l}\text { Discrimination in } \\
\text { intend } \\
\text { Tujuan pemungutan } \\
\text { cukai lebih kepada } \\
\text { fungsi regulerend }\end{array}$ & $\begin{array}{l}\text { Revenue purposes } \\
\text { Justifikasi pemungutan } \\
\text { pajak penjualan lebih } \\
\text { kepada fungsi budgetair }\end{array}$ \\
\hline 3 & $\begin{array}{l}\text { Quantitative } \\
\text { measurement } \\
\text { Ada pengawasan } \\
\text { fisik oleh otoritas } \\
\text { cukai }\end{array}$ & $\begin{array}{l}\text { Selfassessment } \\
\text { Pemungutan pajak } \\
\text { penjualan dilakukan } \\
\text { dengan sistem self } \\
\text { assessment }\end{array}$ \\
\hline 4 & $\begin{array}{l}\text { Single Stage } \\
\text { Dikenakan di } \\
\text { tingkat pabrikan dan } \\
\text { importir }\end{array}$ & $\begin{array}{l}\text { Multistages } \\
\text { Dikenakan pada setiap } \\
\text { rantai produksi dan } \\
\text { distribusi }\end{array}$ \\
\hline 5 & $\begin{array}{l}\text { Unit Tax atau Multi } \\
\text { Tax Rate } \\
\text { Tarifnya berbeda- } \\
\text { beda, tergantung } \\
\text { jenis atau } \\
\text { banyaknya barang }\end{array}$ & $\begin{array}{lc}\text { Single/proportion tax } \\
\text { atau ad valorem tax } \\
\text { Pada umumnya tarif } \\
\text { yang } & \text { diberlakukan } \\
\text { adalah advalorem tax } \\
\text { rate. }\end{array}$ \\
\hline
\end{tabular}

Source: (Rosdiana, 2007)

Apabila melihat secara parsial berdasarkan obyeknya, pemungutan Pajak Penerangan Jalan kemungkinan dapat didekatkan dengan konsep pajak atas konsumsi, meskipun sejatinya pajak atas konsumsi merupakan pajak obyektif.

Di berbagai negara seperti di Eropa, terdapat pemungutan atas penggunaan listrik, namun didasarkan pada pertimbangan yang berbeda. Namun, European Comission, yaitu Eurostat, insititusi tersebut memberikan catatan bahwa pada dasarnya adanya pungutan atas penggunaan listrik lebih difokuskan kepada penggunaan listrik oleh industri tertentu dengan mengusung konsep polluter-payprinciple, yang merupakan bagian dari konsep pemajakan atas penggunaan energi (tax on energy use) (European Commission, 2017). Hal tersebut disebabkan dengan pertimbangan bahwa produksi listrik menggunakan energi fosil yang pada akhirnya akan menimbulkan emisi. Penggunaan energi fosil yang menghasilkan emisi akan menimbulkan dampak negatif bagi lingkungan merupakan dasar dari 
pengenaan pungutan tersebut sehingga dengan dikenakan pajak, maka industri penghasil diharapkan mampu menghasilkan listrik yang dalam produksinya menghasilkan emisi dalam jumlah minimum. Meminjam konsep pajak lingkungan (environmental tax) OECD terkait pemajakan atas energi, disebutkan bahwa "environmental taxes and charges can be classified in a number of ways. An environmental tax is defined as tax whose tax base is a physical unit of proxy of it that has proven specific negative impact on the environment" (Eurostat European Comission, 2013).

Pada sektitar tahun 1920an negara Eropa seperti Norwegia dan Denmark melakukan pemungutan pajak atas penggunaan listrik berupa energy tax. Pemungutan pajak dilakukan kepada pengguna akhir, yang pada akhirnya dilakukan pembahasan ulang apakah pemungutan pajak tersebut telah tepat. Kajian yang dilakukan oleh Finnish Energy Industry pada tahun 2010, menyebutkan bahwa pemungutan pajak atas penggunaan listrik cukup variatif. Namun disebagian besar negara di Eropa, pemungutan pajak atas konsumsi listrik ditujukan semata-mata sebagai upaya minimalisir polusi terutama jika sumber energi pembangkit listrik menggunakan minyak bumi atau batu bara yang sarat dengan emisi, jika sumber energi untuk menghasilkan listrik berasal dari energi terbarukan yang minim polusi, maka electricity tax tidak dikenakan (Finnish Energy Industries, 2010).

Dalam konteks administrasi pemungutan, jika dibandingkan dengan berbagai jenis pajak atas penggunaan listrik di Eropa (OECD, 2013), dimana pemungutannya biasanya dilakukan oleh pemerintah pusat. Pengenaan pajak atas penggunaan listrik diklasifikasikan ke dalam 3 kelompok, yaitu: (a) pajak atas penghasil listrik (dikenakan pajak karena menimbulkan dampak negatif lingkungan); (b) pajak atas kendaraan dengan tenaga listrik (penarikan retribusi karena penggunaan ruang publik); dan (c) pajak atas penggunaan listrik (pemajakan atas konsumsi listrik). Jenis pajak pertama dan kedua dipungut oleh perusahaan, sementara jenis pajak ketiga dibayarkan sendiri oleh pengguna listrik.

Jika melihat kembali ketentuan pemungutan Pajak Penerangan Jalan Indonesia, Pasal 56 (2) menyebutkan bahwa "Pajak Penerangan Jalan yang terutang dipungut di wilayah daerah tempat penggunaan tenaga listrik. Kemudian, Pasal 56 (3) menyebutkan bahwa "Hasil penerimaan Pajak Penerangan Jalan sebagian dialokasikan untuk penyediaan penerangan jalan". Dapat diketahui bahwa pemungutan dilakukan oleh masing-masing Pemerintah Daerah sesuai dengan ketentuan/regulasi yang disusun oleh masing-masing Pemerintah Daerah. Sebagai dampaknya, dengan diskresi yang dimiliki oleh masing-masing Pemerintah Daerah, terdapat potensi bahwa atas konsumsi yang sama akan dikenakan beban pajak berbeda semata-mata karena perbedaan wilayah geografis, meskipun terdapat batasanbatasan tertentu yang diatur dalam Undangundang.

Selanjutnya Pasal 56 (3) terkait alokasi, diberikan keleluasaan kepada masingmasing Pemerintah Daerah untuk mengalokasikan sebagian sebagai penyediaan penerangan jalan. Ketentuan yang demikian, yaitu tidak dimuatnya jumlah atau persentase minimum dan tetap dari besaran pemungutan tersebut sebagai alokasi atas penyediaan penerangan jalan memberikan diskresi yang sangat luas bagi Pemerintah Daerah. Tentu hal ini telah melanggar prinsip transparansi keuangan publik yang merupakan ruh dari New Public Management dan New Public Services, dimana masyarakat berperan sebagai shareholder kegiatan pemerintahan (Klijn E.H., 2012). Selain itu, secara tidak langsung Pemerintah Daerah diberikan keleluasaan untuk menggunakan dana yang dihimpun dengan mengabaikan prinsip efisiensi alokasi anggaran (Arindhayandi, 2018). Dengan demikian besar marginal 
benefit dari marginal cost semakin tidak terukur.

\section{Simpulan dan Saran}

Dalam melakukan desain suatu pungutan pajak, pertimbangan untuk berpedoman kepada konsep dan teori perpajakan merupakan hal yang sangat vital, karena pajak merupakan pengambilan sumber daya dari masyarakat oleh pemerintah. Pemungutan pajak atas penggunaan listrik belum mencerminkan suatu kebijakan pajak yang berpedoman kepada suatu klasifikasi konsep dan teori pajak secara fundamental, meskipun apabila didekatkan dengan konsep dan teori yang ada, maka cenderung dengan konsep pajak atas konsumsi. Dalam pengimplementasiannya, jenis kebijakan pajak tersebut akan berpotensi menimbulkan permasalahan karena tidak didesain secara tepat. Dengan demikian, perlu ada upaya untuk melakukan perbaikan kedepannya, yaitu penentuan jenis pajak yang tepat serta ketentuan pelaksana dan pengadministrasian yang sesuai dengan pilihan jenis pungutan pajaknya.

\section{DAFTAR PUSTAKA}

Arindhayandi, M. R. (2018). Peran Pemerintah Daerah dalam Pelaksanaan Pemerintah yang Baik (Good Governance) di Bidang Pembinaan dan Pengawasan Indikasi Geografis. Jurnal Hukum Dan Pembangunan, 48(4), 883902.

Das-Gupta A. (2015). Non Tax-Revenue in Indian States: Principles and Case Studies, A Consultation Report for the Asia Development Bank. Jakarta.

European Commission. (2017). Excise Duty Tables Part II Energy Products and Electricity.

Eurostat European Comission. (2013). Environmental taxes: A statistical guide. Eurostat Europian Comission. Retrieved

from https://ec.europa.eu/eurostat/documents/ 3859598/5936129/KS-GQ-13-005-

EN.PDF/706eda9f-93a8-44ab-900cba 8 c $2557 \mathrm{ddb} 0$ ?version $=1.0$

Fan, Z.; G. W. (2016). The Fiscal Risk of Local Government Revenue in the People's Republic of China. Tokyo. Retrieved from https://www.adb.org/sites/default/files/p ublication/183033/adbi-wp567.pdf

Finnish Energy Industries. (2010). Energy Taxation in Europe, Japan dan the United States. Finnish Energy Industries.

Giertz. (2007). Excise Tax, University of Illionois.

Hadi, S. (2017). Earmarking Tax Optimization to Support the Effective and Sustainable Infrastructure. Jurnal Ekonomi Pembangunan, 18(2), 194 2014.

Hakim M; Sarma Ma'mun; Hariyanto. (2018). Strategy Peningkatan Pendapatan Asli Daerah di Kabupaten Kepulauan Anambas. Jurnal Manajemen Pembangunan Daerah, 10(1), 15-24.

Hari, A. P. (2012). Kemampuan Keuangan Daerah dalam Era Otonomi dan Relevansinya dengan Pertumbuhan Ekonomi, Studi pada Kabupaten dan Kota se Jawa-Bali. Jurnal Studi Pembangunan Interdisiplin, 21(1), 118.

Hundsdoefer J. [et.al]. (2013). The Influence of Tax Labeling and Tax Earmarking on The Willingness to Contribute - A Conjoint Analysis, Tax Labeling and Tax Earmarking, 360.

Iskandar, A. ; A. S. (2014). Kinerja Keuangan Daerah dan Kesejahteraan Rakyat di Era Desentralisasi Fiskal (Studi Empiris Pada Kabupaten/Kota Provinsi Sulawesi Selatan TA 20082012). Artha Sekolah Tinggi Akuntansi Negara (STAN), 1(1), 79-101. 
Ismail, T. (2011). Implementasi Pajak Daerah dan Retribusi Daerah di Era Otonomi Daerah. Masalah Masalah Hukum, 40(2), 256-260.

Kallhoff, A. (2014). Why societies need public goods. Critical Review of International Social and Political Philosophy, 17(6), 635-651. Retrieved from

https://homepage.univie.ac.at/angela.kal lhoff/wordpress/wpcontent/uploads/2017/05/Kallhoff_Why -Societies-Need-Public-Goods-Art..pdf

Klijn E.H. (2012). Public Management and Governance: A Comparison of Two Paradigms to Deal with Modern Complex Problems. In The handbook of governance (pp. 201-214). Oxford: Oxford University Press.

OECD. (2013). Taxing Energy Use: A Graphical Analysis. Paris: OECD Publishing.

Prathama G.A. (2018). Eksistensi Pajak Daerah sebagai Wujud Pelaksanaan Otonomi Daerah dalam Kerangka Good Financial Governance. Media Iuris, 1(2), 251-256.

Rahman F.A. (2017). Kontribusi Pajak Bumi dan Bangunan terhadap Tingkat
Pendapatan Asli Daerah pada Dinas Pendapatan Daerah di Kota Makassar. Jurnal Economix, 5(2), 104-115.

Richard, B. ; W. J. S. (2012). Designing Tax Policy: Constraints and Objective in an Open Economy, International Center for Public Policy Working Paper.

Rosdiana. (2007). Pengantar Ilmu Pajak Kebijakan dan Implementasi di Indonesia. Jakarta: Rajawali Press.

Scheerens D; Ongevalle J.V. (2018). Strengthening Local Taxation through Decentralized Development Cooperation, Belgian Policy Research Group on Financing for Development and $K U$ Leuven Research Institute for Work and Society.

Szalbierz Z., R.-S. E. (2016). Energy Security as Public Goods. In E3S Web of Conferences 14, 01005 (2017) Energy and Fuels 2016.

Wardhono A., Indrawati Y., Q. C. . (2012). Kajian Pemetaan dan Optimalisasi Potensi Pajak dalam Rangka Meningkatkan Pendapatan Asli Daerah (PAD) di Kabupaten Jember. Jurnal Teknik Industri, 7(2), 69-76. 